$\mathbb{T}$ periodica polytechnica

\author{
Social and Management Sciences \\ $20 / 2(2012) 81,90$ \\ doi: 10.3311/pp.so.2012-2.03 \\ web: http://www.pp.bme.hu/so \\ (C) Periodica Polytechnica 2012
}

RESEARCH ARTICLE

\section{Sustainable public transport: A Central European Study}

Anikó Kelemen-Erdős

Received 2012-05-27

\begin{abstract}
The paper studies the sustainable development opportunities of the public passenger transport market. The main aim of the research is to improve the competitiveness of sustainable public transport. The study focuses on the main problems of the industry and on the exploration of solutions to these problems; therefore grounded theory is applied based on qualitative in-depth interviews of experts in Hungary.

The research aims to explore transport policy and analyse marketing tools for encouraging public transport demand, while generating debates on intervention issues, in order to either confirm or impugn the present situation. The resulted grounded theory has brought attention to the necessary reform of transport institutions; to transport policy integrated settlement development; to public transport development proceeding from supply improvement; and finally, the need of improving awareness via education. The conclusion of the research is also that external fund allocation is necessary, via such means as emerging liberalization and public-private partnership, and that more demand responsive transport should be introduced, while taking into account sustainable consumption.
\end{abstract}

\section{Keywords}

Transport planning $\cdot$ sustainable public passenger transport . sustainable consumption - marketing strategy $\cdot$ qualitative research $\cdot$ grounded theory
Anikó Kelemen-Erdős

KGK GTI, Óbuda University, 1084 Budapest, Tavaszmező str. 17., Hungary e-mail: kelemenerdos@mail.com

\section{Introduction}

The transport industry is characterized by the market liberalization process and the financial restrictions of the economic crisis, and as a consequence of the latter, the subsequent financial, restrictionary measures that are placed upon it. Nevertheless, sustainable mobility, the enhancement of public transport competitiveness and service quality should be expected for sustainable development.

Transport policy and strategy, along with corporate strategy, determine a company's competitiveness, efficiency and its relation to their macro- and micro environment. These generate several complex social, economic and political questions.

The aim of my paper is to identify the development trends of public passenger transport, to highlight the industry and utility operators which create major problems, and to find solutions and generate ideas and debates that may improve sustainability. Previous literature does not try to explore the root of the industrial problems in Hungary, neither that in any of the postsocialist countries, thus this paper attempts to fill this gap. The study investigates the public transport development opportunities with qualitative in-depth interviews, applying grounded theory for the analysis. As a result it introduces transport policy and corporate strategy guidelines.

\section{Research method}

The reason for applying an exploratory qualitative research method is due to the fact that there has been a need for more accurate definitions of problems and necessary measures. The previous quantitative study on the public transport industry could not identify the reasons for the problems [20]. Since that time, the market environment has changed significantly, due to the international financial and economic crisis, the newly introduced EU directives, the political situation and developments in technology (e.g. mobile and online ticket purchases spread). The liberalization of the road and rail sector has affected a significant presence of private capital in many parts of Europe (United Kingdom full privatization). As such, in order to explore the macro and micro environmental changes, in-depth interviews were conducted. 
In-depth interviews have been adopted in transportation planning, principally to explore travel behaviour [15, 16, 32] such as modal choice [24]. This data collection technique was applied in such research for understanding the consumers' motivations, perceptions and attitudes. Unlike such studies, this paper investigates the supply side and the feelings of transport planning experts. The in-depth interview method is suitable for exploring the views and attitudes of respondents to the public transport market. The direct research process is flexible, allowing a deeper understanding of the weaknesses and opportunities of the politicized sector. The personal, anonymous response option contributes to the understanding of those topics, where the experts are divided, such as in economic, transport and social policy. The vast majority of open questions, in addition symbolic analysis techniques are applied [25].

Grounded theory is a generally accepted qualitative method, and it has received a lot of constructive criticism. First of all, because the researcher should not have perceptions about the theme prior to the research being carried out, but this is sometimes inevitable. Also, the coding procedure is very long and unclear in the description of the founders, Glaser and Strauss [13]. However, over a period of time the method has improved sensitively [1,22]. Grounded theory is frequently applied as an analysing method in transportation research (e. g. [12,13]). The aim of that method, on the grounds of attempting to understand the problem and its solutions, is to identify propositions and a conception. On the basis of propositions, which should explore patterns and deficiencies, can be formulated the final grounded theory [39].

The method validates the results by comparing them with earlier findings, although it does not sit in judgment on the resulting theory, or confirm whether it is acceptable or not [14,36].It analyses only if the theory fits into the earlier research results, even if the concept can be modifiable. The relevance of the study, especially the respondents, should be investigated through the process. Further on into the investigation, the resulting grounded theory should introduce several solutions for the problem [14,36].

The research has been conducted according to the principles of grounded theory, thus new participants have been drawn into the study, and new information has emerged. The range of respondents has been identified with consideration method arbitrarily, according to the reputation and job classification of experts. The interviewees are industry-wide informed, strategic planning leaders; such as executives of transport universities, research institutes, ministries, national public transportation companies and owners, who are at the same time, senior analysts of their transportation consulting companies. All of the participants are, or formerly used to be, a member of an international organization or fund, for instance the OECD, the PHARE, the UITP, the EBRD, the EIB, the World Bank and the American Chamber of Commerce in Hungary. They are all seeped in the knowledge of worldwide trends and in connection with foreign service providers. As a consequence, they have become aware of many personal, national and international experiences related to the industry, and due to this, they have regularly referred to benchmark, best and innovative practices.

The research is in accordance with the qualitative method, and the features of the sampling are not representative, but it is suitable to define a theory.

\section{Data analysis}

Grounded theory has an abductive approach, especially as it has inductive, and also deductive elements [7]. It is inductive, because the theory is derived from responses; in turn, this is deductive, because the results are compared to the literature, which is also called theoretical sampling. Theoretical sampling means that literature is included in the course of the research as new data into the process; for this reason, the paper does not provide a separate literature review [14].

The semi-structured interviews are tape-recorded and transcripted. After open coding, the similar ideas of the respondents and also the so called memos ${ }^{1}$ are labelled and grouped into discrete incidents [36]. Theoretical coding ensures that data emerges from the relevant literature and other background information, such as statistical data, which are involved into the research to validate findings. According to axial coding, the categories were related to each other through comparative analysis, in order to explore the relations among them [36]. The data have been reduced through selective coding [26, 36]. In this way, broad coding categories have emerged [35] until the core variable, "sustainable public transport" has been identified. The results are presented according to the three main subcategories, which are supported by the core variable, such as the "problems of public transport", the "solutions for public transport" and the "future of public transport".

To interpret the main findings and the relations between the subcategories, detailed figures (Fig. 11. Fig. 2 and Fig. 3) are included. However, these figures should be treated as a whole, as several categories also have an effect to another category in another figure.

\section{The main problems of public transport}

Selective coding has resulted in the subcategories of "problems of public transport", which are illustrated in Fig. 1. In this way, the basis of the problem-solving approach of sustainable public transport is identified. The figure depicts the broad coding categories, and their relationships.

The prevailing political conditions define the macro and micro environment of the companies, which when combined with persistent underfunding problems, leads not only to indebtedness, but also to the impossibility of planning. In addition to this, because of the constant changes to organizational structures and the large-scale fluctuation of management, the executives end up

\footnotetext{
${ }^{1}$ Memos are notices about the theme.
} 


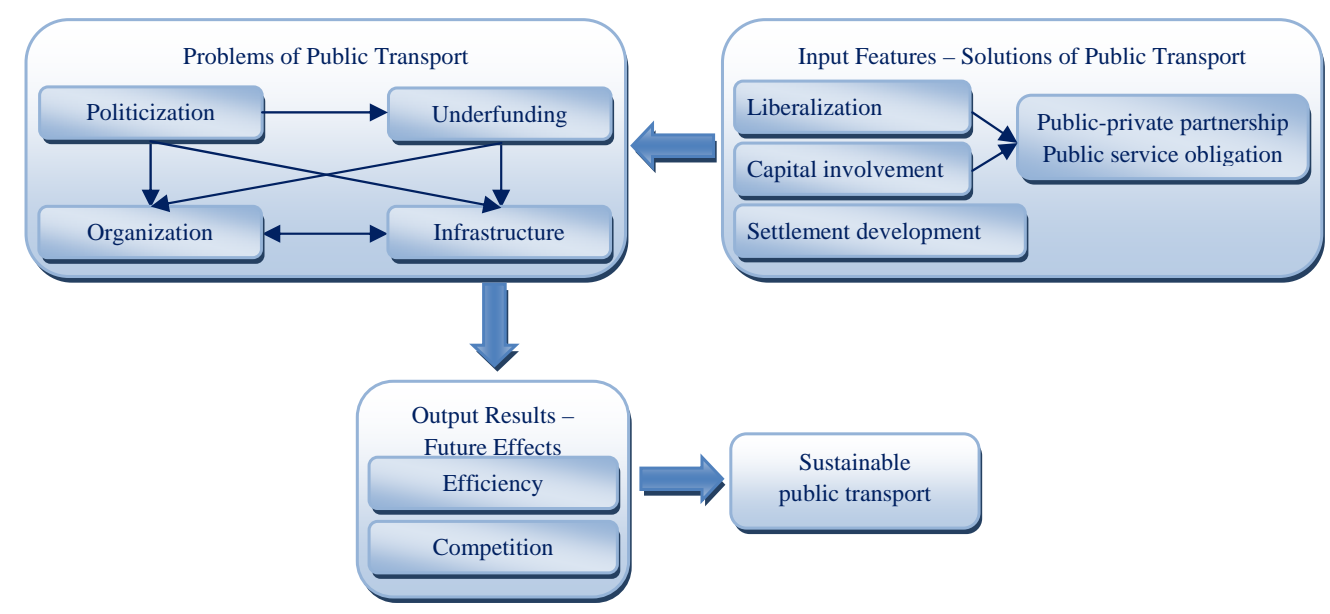

Fig. 1. Problem-solving of sustainable public transport development

having an interest predominantly in short-term results. This is a situation that is basically out of accord with the long-term development needs of the sector, for the transport service quality can only be improved in the long term. The organizational problems are also related to the completely inflexible instruction system, which does not allow for the shaping of the market.

The need for subsidies is in part due to the fact that the cost of the public service can not be diverted to the consumer, since public service should be widely available to ensure the access of public institutions, jobs and more individual travel needs (visiting relatives, tourism, shopping ... etc.). Several problems are continuously affected by the lack of resources, including the condition of the infrastructure, especially the receiving ability and condition of train stations, the track conditions, the permeability of the lines, network optimization, schedule planning, the development of the passenger information system, as well as the quality of service. The infrastructure improvement should be coordinated with the development of the settlement because sustainability deserves, when mobility needs do not arise. The need for mobility is not the only demand, because industry is also affected, therefore the priority is to deal with the negative externalities and social issues [30]. This is closely related to the development of peripheral regions. It is beneficial for residents if the necessary institutions are easily accessible by bike or on foot as they do not have to spend hours travelling per day; additionally, if transport demand does not arise, then this is the basis for sustainability. In accord with that, since transport is based on a derived demand, the sustainable transport system should be based on a specific transport vision in which social and ecological sustainability should be pursued [27].

Transport and rural development politics may have an effect on population density, the availability and popularity of public transport [19]. Availability and accessibility, which are the scope of public service, should be ensured in order to reduce the negative externalities. From a political point of view, changes can be achieved if rural and public transport infrastructure developments are in parallel with the introduction of user charges.

In spite of the continuing lack of resources, the quality level of public transport service is decreasing, only isolated improvements take place. Should funds remain unavailable, the quality may decline irreversibly. European Union development funds have been spent particularly on road development and on electrifying the rail network of GySEV. Albeit the EU does not force the development of railways in areas where the road may be preferable, it still stresses the importance of sustainability principles.

The interviewed experts disagreed on the issue of rail infrastructure. Several interviewees questioned, whether Hungary needs to maintain and develop such a dense rail network. Some of them suggested that only the powerful, reliable part needs to be maintained. From the released financial resources that would arise from no longer needing to perform network maintenance and operations on closed lines, other areas could be financed, such as the technical and service quality, the reliability of traffic management and the passenger information systems. However, in areas of lower population density, the benefits of railways were also stressed. In these areas the regional lack of ability, the poor municipalities and the aging population feature even more, and as such, the authorities are not able to maintain the system independently.

The proposition, that is to say, the consequence from the problem point of view is the following: settlement development should be harmonized with public transport development to ground the basis of sustainability.

\section{Proposals to solve the identified problems}

\subsection{Private capital involvement}

The owners of public transport companies can have two basic priorities. The first is to develop a supply market and thus increase the share of public transport. The second is to achieve a significant reduction in public financing which can be achieved by market liberalization. However, this second policy allows only a few political requirements, such as reductions for social groups. Another important dilemma is whether the service provider is considered as a market player, or a public, or a budgetary institution. Insofar as the owner seeks full benefits or 
increasing efficiency, these can cause disruption in supply and neglect of social aspects.

The state is unable to finance and maintain the public transport system, hence the importance of private capital involvement (Fig. 11. The investors expect, at least in the long term, profit and security, therefore, more predictable planning and operating conditions would facilitate the involvement of private capital. A great care must be taken if the principles of the public are not to be jeopardized. In the course of liberalization, safety aspects must be also taken into account. One of the interviewees believes that the public passenger transport companies should be privatized as in freight transport, which would serve the improvement of financial resources, including technical and productive efficiency, while not narrowing the scope of public service. Another respondent has drawn attention to the importance of caution in relation to the Great American Streetcar Scandal, where well-capitalized companies (General Motors, Firestone Rubber, Philips Petroleum, Standard Oil of California, Federal Engineering Corporation) purchased the streetcars and the trolleys in the large cities of the United States of America, in order to shift track traffic to road transport, and consequently, to replace them with their own products [17]. Along these lines, public-private partnership (PPP) oriented regulations should be introduced to develop the industry with control to the social perspectives, security and quality [33,34]. In the regions of the United Kingdom outside of London after privatization, market demand was assessed, and following that, only in those areas which were shown to be profitable, was the service continued, and so some areas lost access to rail. However, this can result in strong social and political tension, as has occurred in France and Slovenia at certain weekends.

The problem in investing in rail development is that, a concession of at least 20-50 years is required to return, and that instability prevails even in the short-term. For this reason, private equity does not appear to be attracted to the industry, although perhaps this might not be always true for a very well-capitalized company that has significant additional benefits, such as improving the quality of labour, positive social assessment as a compensation of negative externalities, or the creation of captive markets for their products.

All public transport companies have already outsourced some functions which are not related to transportation in Hungary, but there still remains more potential in this area. Primarily in tourism targeted lines and destinations, including the Buda Castle Funicular, the Chairlift, the Cog-railway, the second tramway line along the Danube bank and the further operation of nostalgia vehicles. The improved utilization of the Danube as a riverway could also help to ensure sustainability.

Private capital can be involved in the introduction of electronic ticketing systems or multi-modal interchange nodes. The multi-modal interchanges can realize a higher level of interoperability, thus these can unitize the technical, corporate, juridical and cultural interoperability [28]; although in general, transport policy makers can decide to orient towards one of them. The multi-modal interchange nodes take the form of PPP in several countries. The transport associations should co-ordinate the operators and other decision makers. However, in the case of $\mathrm{Ke}$ lenföld, a good opportunity would have been to develop a modern multi-modal junction, since all transport modes have been reconstructed or newly built. Inasmuch as the development of integrated junctions, which performs several functions and services, benefits the passengers, it also benefits the investors by the reduction of investment and operating costs. In addition to this, there appear to have been other missed opportunities at reconstructed undergrounds in Budapest, such as the lack of elevators leading to the subway system.

Further opportunities exist in integrating flexible transport systems into the existing one. At these systems, the potential passengers sign their travel demand in the demand responsive transport system, and then the dispatcher centres optimize the flexible time and/or route (see detailed in [5, 6, 29]). Europe has primarily adopted flexible transport modes in small communities and has done so as a social benefit for elderly or disabled people. In addition to scheduled services, it can perform a feeder function in low-traffic periods and/or areas. To a lesser degree, it can be operated instead of the traditional transport modes. The demand responsive transport system can also be introduced with subcontractors who can operate with their excess capacity, occasionally during the rush hour, or in turn during off-peak periods. As a result the following propositions can be formulated:

- To allocate financial resources and reform public transport companies, liberalization should emerge regarding the scope of public service, and moreover, outsourcing should be continued.

- Public-private partnerships should be established to develop demand responsive transport systems and multi-modal interchange nodes, as well as introducing electronic ticketing systems.

\subsection{Advice for the formulators of transport policy guidelines}

Sustainable transport development should be applied founded on basic priorities, such as availability and accessibility. Such key points characterize the analysing process, so are also referred in connecting with the future and marketing (Fig. 2). The structure of the transport institutions places transport policy within definite bounds. According to the experts and the consultants of the public transport companies, the efficiency of transport policy could be achieved more readily and effectively by the separation of ownership and management; especially in the area of order and control of public service.

A stronger intervention of transport associations is required. There is a need for regional authorities to coordinate transport that operate from the owner and the ministry independently. Tasks would include tariff and output optimization by the analysis of market demand; service ordering and financing; market 


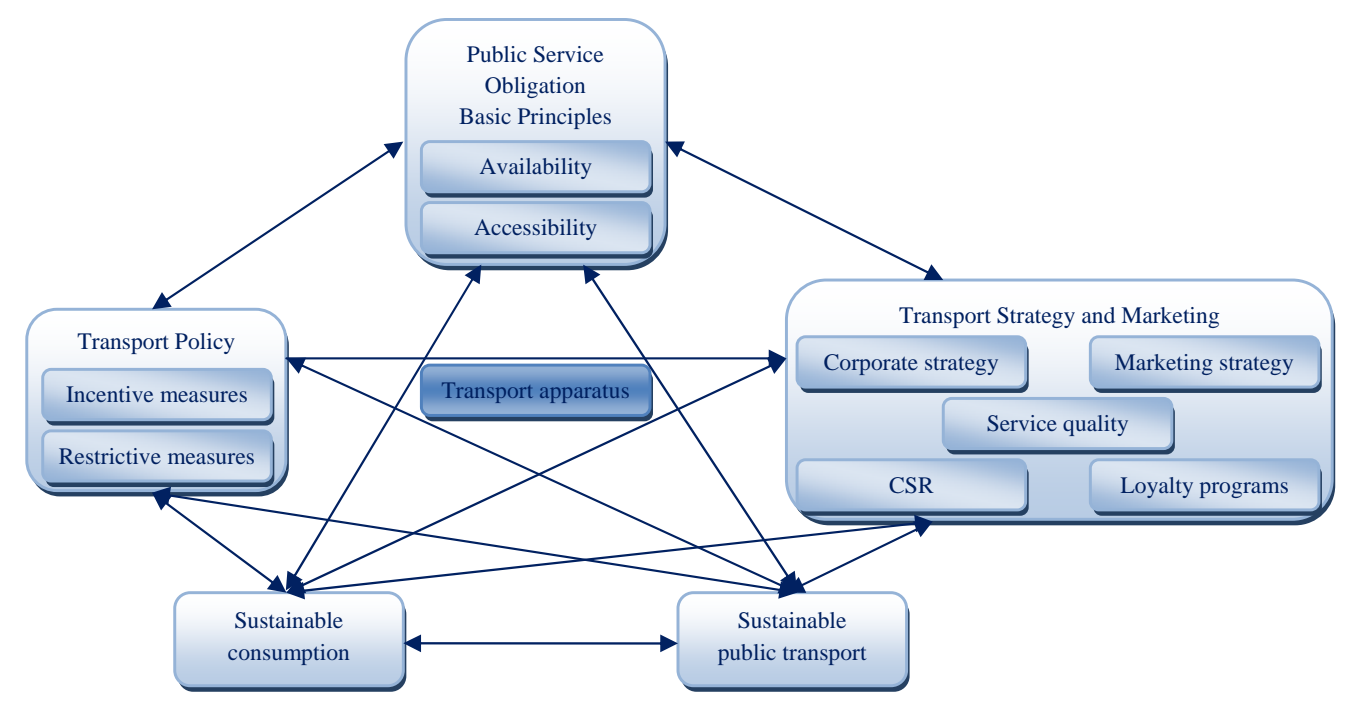

Fig. 2. The starlike model of sustainable public transport strategy

monitoring, and finally, the operators' coordination to avoid duplication of traffic. Market efficiency could be increased if the concessions were launched in a competitive environment. The operators can only increase revenue if there is an increase in the number of passengers. However, in liberalized markets, the private operator may determine the service, focusing on the where, the when, the how often, and ultimately, whether to provide a service at all. According to the interviewees, privatization is likely to slightly increase the price of transport, along with the quality level of services in Hungary. However, the private bus company Weekendbus acts as a counterexample to this opinion, by providing a high quality, profitable service at officially maximized fares on the Budapest-Csömör route; while the state provides subsidies only after the categories of beneficiaries. Based on customer needs, Weekendbus has launched a new route between Csömör and Pécel, where the number of passengers is growing and it has already reached the break-even point.

Several respondents mentioned that the lack of system integration can be illustrated with the school bus system. This operates in parallel with other transport modes, and thus consumes parallel public funds that could be used elsewhere. In addition to that, involving new capacity (school buses) reduces the efficiency of the existing public transport. However, it also has a number of positive attributes: it can be favourable for students and their parents, and in the long term, this may become the cornerstone of children's environmental education. Parents will also prefer the school bus system due to the fact that teachers offer their children safety and supervision on the buses. The mobility needs of parents are reduced thereby declining the environmental and social costs. They do not need to travel to school and from there to their workplace; therefore they have the opportunity to start work earlier.

Most of the experts believe that there are no additional costcutting possibilities, up to transferring costs and introducing modernised cost management schemes (detailed in [4]). Instead, more should be spent on public transport because utilization of modern technology would lead to an increase in the level of service and the retention of, and the increase in, the number of passengers. Although, the implementation of technological development is regularly not accompanied by an increase in efficiency. For example, the acquisition and operation of air conditioning equipment is not cost-effective; and low-floor buses have lower capacity, and so in this way, smaller or larger board congestion may occur. As such, improvements in the passenger vehicle fleet need to be in accordance with operational development; an important factor in increasing efficiency.

One interviewee suggested diminishing tariffs by $30-40$ per cent, which also could contribute to prior public transport. The respondent estimates that the volume increase would be about 20 per cent, if at the same time priority measures are introduced to public transport and restrictions are introduced to private transport (such as congestion charging and parking fare increase). While this may ultimately lead to a decrease in revenues, it must be decided whether the target is sustainable development, and therefore public transport is the priority, or whether the target is just efficiency. If the target is the former, then polices to reflect this should be implemented. Such policies were studied in Spain: abolishing VAT on public transport fares, while imposing fuel taxation [2]. The purpose of the research was to increase the accessibility and usage of public transport, in addition to reducing congestion and environmental pollution. Clearly such policies may have a financial impact on society, and living standards may drop due to an increase in taxation. However, the aim is to keep any such knock-on effect to a minimum.

The incentive and restrictive measures should be applied together to achieve sustainable public transport development (Table 11. First of all, the elements of supply, the service and the reliability standards should be developed. Then public transport should be officially preferred and enshrined and enforced legally. At the same time, restrictive measures should be introduced, which also increase the relative level of public transport 
compared to individual. These can be a variety of measures; the most extreme form is the prohibition of private transport that should be applied primarily in historic downtown areas. Private transport may be limited, inter alia, by creating one-way streets, using street furniture, prohibiting parking and stopping and introducing speed limits. It can also be encumbered with bus lanes and parking clamps and via integrated charging policies with parking and congestion fees. However, these only affect destination traffic and do not pose a problem for transit traffic. The excessive application of restrictive measures might improve public transport journey time, although there are potential negative factors that may arise from such measures: because bus lane congestion can occur on roads and traffic can increase on other routes, which then raises the overall environmental impact.

The prerequisite of combined public transport is that, $\mathrm{P}+\mathrm{R}$, or $\mathrm{P}+$ Walk parking spaces or even bicycle storage devices should be provided, thereupon reducing the environmental impact and congestion. The motorists need to be convinced through transport marketing tools, that they can save either money, or time, or both, when their cars are stopped. For example, the closest parking places to Dublin DART light rail have to be paid for in the suburban areas, although a little further away, but within 50 meters, free parking spaces are provided. Different levels of restrictions can be imposed in more stages along the ring roads of Budapest. Congestion occurs mainly on radial inbound traffic in the downtown area. The interconnection of the outside districts of the capital would be particularly important as they are linked to the endpoints of downtown lines. The strengthening of peripheral centres could also serve the purpose of decentralization, which tends to reduce the load of the city.

Public transport development leads to a local pay off, and thus areas or regions become more integrated and develop. Therefore, local transport should be funded from local taxes levied to the secondary beneficial. As respondents add, local taxes may be imposed for employers' transport to workplaces, or their car usage may be taxed in the form of entrepreneurial or property taxes.

Parking fees and congestion charges should also be introduced to finance public transport. Employees should be encouraged by the fringe benefit system to prefer public transport. If this is tax free, then the employer may also prefer to provide such benefits, and those employees who are able to choose, would more likely select from the incentives. Congestion charging could be an effective measure for modal shift to public transport. Modal choice can be influenced most effectively by travel time or cost reduction (market liberalization, traffic management, tariff reduction, new transport routs). Those measures, that increase cost and/or travel time of car usage (speed limit and control, petrol price increases, parking policy, infrastructure charges, internalization of other costs), increase the government revenues, but there are still too many external social costs [18].

Nevertheless, traffic experts agree that such a large discount system is unaffordable for public transport. However, passen- gers feel that discounts are a basic right, so they evaluate negatively any restriction on them, even though they do not take into account such discounts. Such a wide-range discount system exists nowhere within Europe, but Hungary should provide it for all EU citizens. One of the transport experts suggests a new approach is needed. He believes that social affairs or education ministries should provide discounts. Another respondent proposes that in order to optimize free travel under the age of 6 and above 65 , the opportunity to travel free should only be provided outside of peak periods; within the rush-hour, a fair social benefit for these groups should also be provided.

Performance-based pricing is necessary also for Budapest local transport, because passengers currently pay the same amount if they travel only a few stops, as they do for a journey that takes them along a whole public transport route; except in case of section and transfer tickets. An electronic ticketing system would be able to determine accurately the consumption. In this way, tariffs could be calculated on the basis of the completed trip. However, tariffs are neither proportional to income, nor take into account people's ability to pay. Railway transport fares have almost doubled (increased by 93.4 per cent) since 2005, which makes it the second largest increase within the EU; although bus prices have increased to a lesser extent by 37.3 per cent during 2005-2010 [10].

Since 2007 , the bus and railway intercity tariffs have been uniform, although smaller differences may occur due to the calculation of kilometres between them. Thus the tariff does not play a role in transport mode choice between rail and bus. However, when considering transport options as an individual, fares increase in importance. In case of two travellers paying the full price for a journey, it may be preferable to travel by car, particularly if we take the comparative advantages into account. When considering private transport, the potential passengers do not take into account the depreciation of the car, the service and insurance costs, the risk of travel, social costs and environmental damage. These are taken as sunk costs; in addition, convenience may also take priority. Therefore the role of raising social awareness in transport policy is particularly important.

The interoperability must also be created between the transport modes by season tickets. The passenger should have the possibility to choose the most advantageous transport mode in each journey. As a prerequisite, an inter-company accounting system has to be established.

Shaping capacity of vehicles to passenger flow also needs to be improved. There is a potential in integrating minibuses into the transport system in the urban and intercity transport, even in the form of flexible transport. A number of cases were referred to in the interviews, for example, minibuses are suited for smaller passenger traffic sections or periods in Barcelona, and the excess capacity of trams is loaded outside the peak period in Prague.

The results can be advised for transport policy. 
Tab. 1. Advices for Transport Policy Guidelines

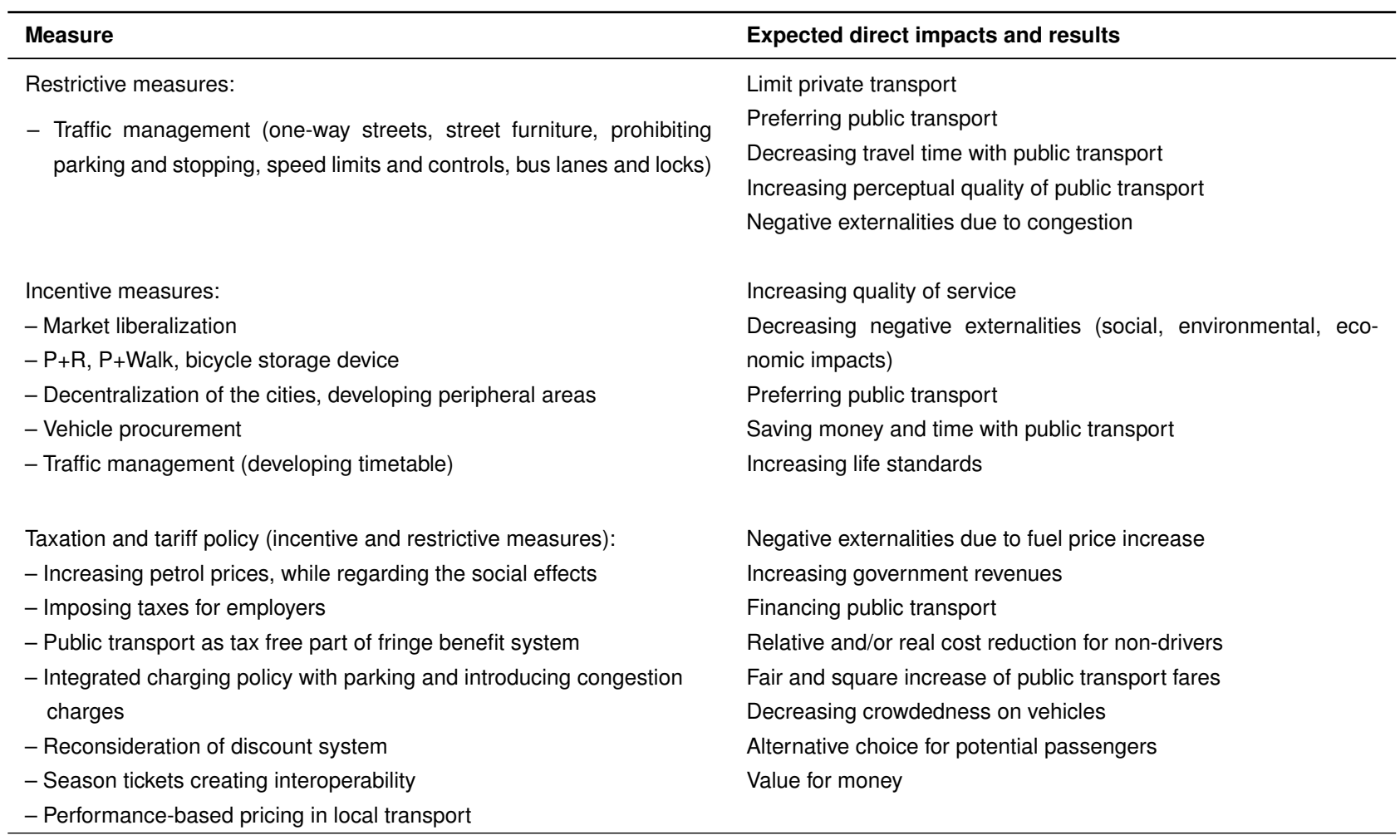

- The institutions of transport and their roles should be reconsidered in light of the liberalization process including the state, the ministry, the regional authorities and the associations.

- Incentive measures should be implemented for increasing service quality and preferring public transport to retain and attract passengers, concurrently restrictive measures should be undertaken for private transport.

- The tariff system has to be reformed, first and foremost the discount system has to be reconsidered and performancebased pricing should be adopted.

\subsection{Transport marketing}

The respondents emphasized the segmentation of the passengers by consumer behaviour according to their companies' own market research, and so highlighting different manageable problems along with the components of service quality for passengers. Commuter traffic accounts for 60-80 per cent depending on time and place; this is the great majority of demand. This segment includes the young, the elderly, and those who because of their age or health status may not drive or who cannot afford an automobile purchase or maintenance. For this largely inelastic segment, accessibility, availability and journey time is the most important factor. If the transfer is not provided for this group, social segregation occurs. The transport system of Switzerland was designed specifically with this group of commuters in mind, thus the connections are strictly calculated.

The others, who have flexible demand, and thus have in part negative income elasticity and are in part price-sensitive, should be encouraged with marketing tools. These narrow segments consciously take into account such factors as traffic conditions or economic issues. In the case of even narrower niches, opting for public transport derives from being aware of the issues of sustainability, or it may be that they simply like public transport. Quality of service is the most important factor for these segments. In order to attract passengers, the service quality of public transport should be compatible with the primary alternative: the car. Consequently, the rapid door-to-door transfer of passengers has to be ensured via the access to multi-modal transportation systems.

Door-to-door transport consists of the time spent on the approach to transportation, the waiting and the running time and the changes. Individual factors can also influence each other; the traffic can be optimized with satellite-based management systems. The optimization of stops is particularly important by reason of availability and accessibility of public service, while increasing the number of stops attends the growth of travel time. The network density of all 4 operators (MÁV, VOLÁN, GySEV, and BKV) is outstanding in Europe, although at the same time, service frequency is lagging behind. If the service is not dense enough, especially in long-distance transport, the emphasis is on accuracy, which depends partly on the service process, and partly on the function of infrastructure. This is a feature, which almost all of the operators should develop, all the more so, since it is very important for passengers. Transport operators highlight further attributes to improve, such as reducing congestion, the risks of inaccuracy at transfers, increasing reliability and punctuality. The transfer of passengers involves such a high risk of 
something going wrong, that they are willing to choose a slower and more uncomfortable transport mode to avoid that. This is not surprising as passenger delays still occur due to the lack of intermodality and interoperability; that is to say, buses and trains do not wait for each other. The conditions of service, cleanliness and especially the attitude of the staff are mentioned as further influencing factors. The operators are in the crossfire of passenger complaints, and almost all service providers are seeking to improve staff motivation and behaviour, with varying degrees of success. To achieve greater results, financial resources are necessary for human resource development.

The annual seasonality is easy to manage, but the daily seasonality is more difficult. Researchers at the University of Leeds assessed, that off-peak price reductions are less effective, than raising fees at peak periods, although such policies are restricted by official prices [38].

The need for real-time, interactive passenger information systems has been highlighted by all operators. It has been realized for example on RailJet trains. The operators also add that the implementation of such a system is not only feasible via investment, but also with better coordination and communication within and between the service providers.

The company leaders stressed that, as a consequence of liberalization and the increasing intra- and inter-modal competition, their focus is on developing customer loyalty, therefore various loyalty programs have spread. However, they are only marginally effective, as customers join these programs only because of their supplied advantages, which are financed by the companies [23].Moreover, the share-of-wallet is independent of the offered benefits. However, it should be able to signify attitude, commitment and stimulate action. Indirectly, CSR (Corporate Social Responsibility) has a similar effect, which can engender consumers to develop a long-term support for the company, increasing not only loyalty, but also actual use of the service. CSR can be effective when it is integrated to the company's core activity [8].Loyalty programs and CSR should also take into account sustainable consumption, thus it should be built into the corporate and marketing strategy (detailed in [37].

The derived proposition refers also to transportation planning: multi-modal, door-to-door transport systems should be developed. In addition, the transport marketing field should consider the following: public transport companies should build passenger loyalty to retain customers.

\section{The future of public transport}

According to the interviewees, in the future, the share of public transport is expected to continue to lose market share in most of Europe, as well as in Hungary. After that period, it should stagnate, and because of the result of sustainable development strategies, public transport should improve again. However, the public transport market is much the largest (38 per cent) in Hungary within the EU [9].

A fundamental difference between the well-developed count- ries with economic potential and the post-socialist countries is in social attitudes and education (Fig. 3). Not only are the countries as a whole, but also their citizens are much more environmentally aware. In the more developed countries, where motorization and the environmental load are higher, but the financing problems are less conscious, focusing on public transport development and improving sustainability are key issues, although France and Italy are exceptions. In order to reduce air pollution, the bicycle is used over smaller distances. This is the case in the Netherlands; however, owing to the comparative advantages of private transport, significant investments and efforts have so far failed to achieve more results. Despite the low achievements, environmental awareness continues to be taught to children.

The large cities of Europe have already been saturated, and except in some places, the available infrastructure can not be expanded any further. As a result of individual motorization, congestion has become a major problem and the quality of life within the cities is threatened. Therefore, states have been working on concepts such as compensating private transport and redefining public transport. The negative externalities and dependence on state resources should be reduced, and that is why rail transport is preferred. Guided ground transport is more sustainable, therefore for example, in Madrid more than 100 kilometres of metro lines were built between 1995-2006 2 There are currently fourteen underground lines, which are more than four times longer per capita than the metro of Budapest. The ticket is 1.1 euro in Madrid, which is about equal to the price in $\mathrm{Bu}$ dapes ${ }^{3}$, but it can be used in a 8.9 times longer track and if we analyse it in GDP per capita in Purchasing Power Standards, it is by 41.6 per cent more favourable (calculated according to the data of Eurostat [11], KSH [21], and Observatorio Ecónomico [31]).

The conclusion of this stage of the research can be formulated as the next proposition: education and public transport development is necessary to improve sustainability, thus public transport preferences.

\section{The developed grounded theory}

The framework of the grounded theory process has been outlined as the problem-solving approach of sustainable public transport (Fig. 4). This framework provides an overview of the results.

According to the grounded theory process, the theoretical propositions are generalized and defined in the following concept: the main pillars of sustainable public transport development, which determine the attraction and retention of consumers, contain settlement development, the reform of public transport institutions, public transport liberalization (including

\footnotetext{
${ }^{2}$ Madrid is the second most populated city in the EU with its 3.3 million residents. If the suburban area is also taken in consideration, it is the sixth with 6.4 million inhabitants. Madrid possesses the second largest metro line with 284 $\mathrm{km}$, only the metro network of London is larger (Observatorio Ecónomico [31]).

$3290 \mathrm{HUF} / \mathrm{EUR}$ exchange rates are considered.
} 


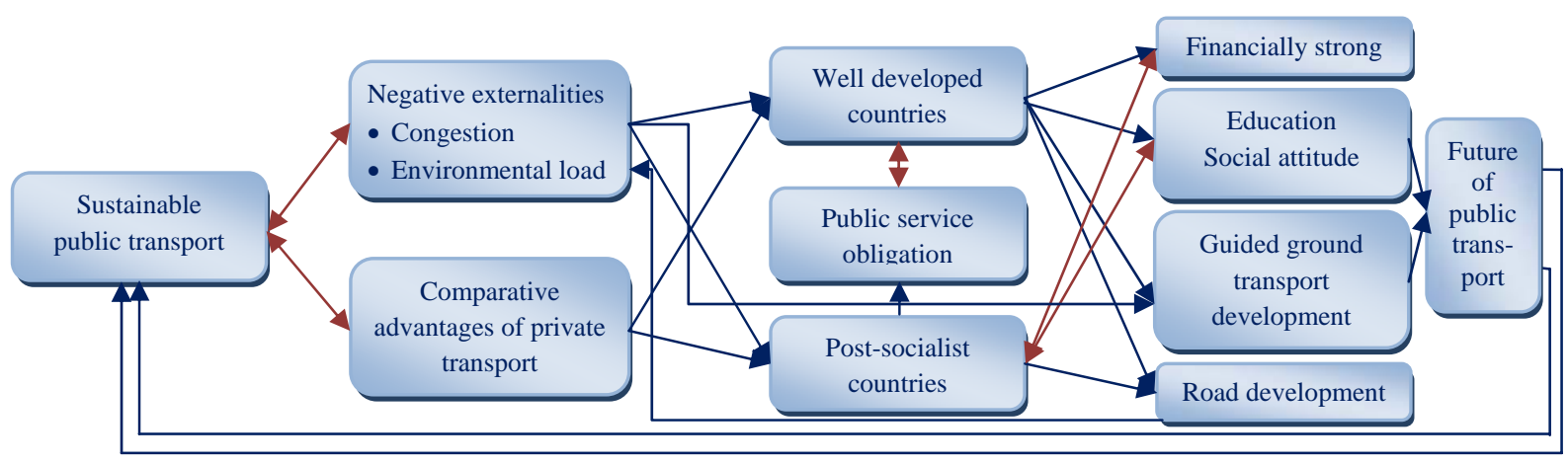

Fig. 3. Results of selective coding, the main subcategories of "future of public transport"

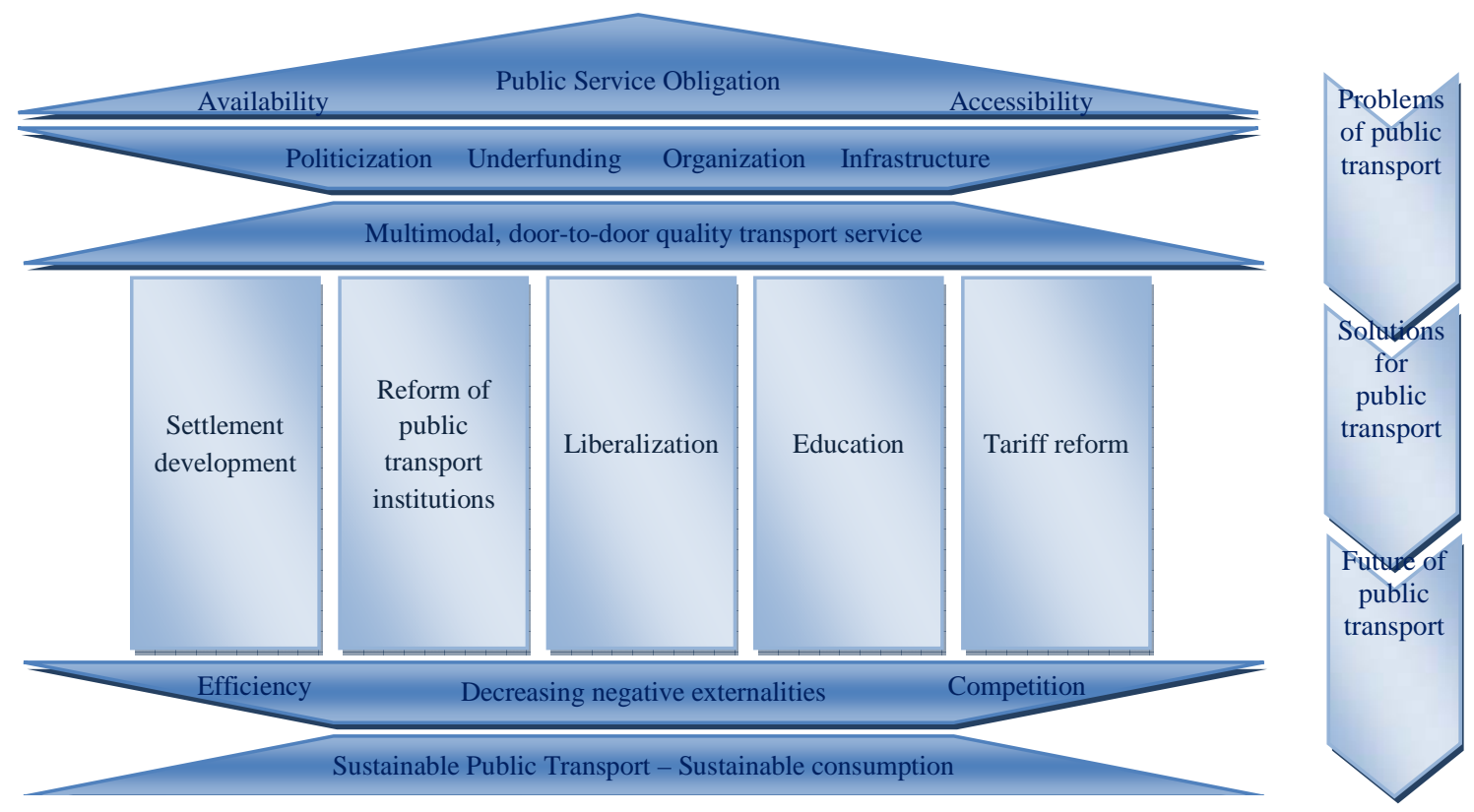

Fig. 4. Problem-solving approach of sustainable public transport

private capital involvement), education and tariff reform, while at the same time focusing on door-to-door multimodal transport development, and as a consequence of that, making quality of supply a key issue. These are the cornerstones in decreasing the identified problems of sustainable public transport development, such as politicization, underfunding, infrastructure and organizational issues, while contributing to sustainable development.

\section{Conclusions}

The results focus on the grounded theory, which can be explained as the following: first, the problem-solving approach of sustainable public transport; second, the necessary measures for sustainable transport strategy; and finally, the main guidelines on how to develop transport sustainably in the future.

The conditions for the operation of public transport systems are determined by political constraints, which are then reflected in the institutions of transport, in the continuous reforms of companies, in the accumulation of debt and in the conservation of the high and dry infrastructure. A way out of this crisis can be the EU market liberalization process, due to its increasing of competition, which contributes the revival of the companies, and thus a higher level of consumer satisfaction. Public transport supply should be improved, even with external financial resources allocation, while sustainable consumption should be taken into account. Apart from incentive measures, the restrictive arrangements can also increase the attractiveness of public transport. Nevertheless, the principles of public service can not be compromised and the availability and accessibility of the service must be ensured for all consumer groups.

For developing public transport, a key element should be settlement development, inasmuch as mobility is based on derived demand. Public-private partnership can be a solution for lack of financial resources in the case of modernization and reforms, such as flexible transport integration and other organizational and technological novelties.

To improve the future of public transport, a sustainable system should be established. There is also a need to focus on awareness; an element that should be reflected in education. To retain and attract passengers, and to comply with their needs, door-to-door transport should be centred in the strategy. 


\section{References}

1 Alan G, A critique of using grounded theory as a research method, Electronic Journal of Business Research Methods 2/1 (2003), 1-10.

2 Barros C. P, Prieto-Rodriguez $\mathbf{J}$, A revenue-neutral tax reform to increase demand for public transport services, Transportation Research Part A 42/4 (2008), 659-672, DOI 10.1016/j.tra.2008.01.027.

3 Beirão G, Cabral J A S, Understanding attitudes towards public transport and private car: A qualitative study, Transport Policy 14/6 (2007), 478-489, DOI 10.1016/j.tranpol.2007.04.009.

4 Bokor Z, Költségtervezés a városi közforgalmú közlekedésben (Cost planning in local public transport), Városi közlekedés 50/2 (2010), 96-99.

5 Brake J, Nelson J D, A case study of flexible solutions to transport demand in a deregulated environment, Journal of Transport Geography 15/4 (2007), 262-273, DOI 10.1016/j.jtrangeo.2006.08.006.

6 Brake J, Mulley C, Nelson J D, Wright S, Key lessons learned from recent experience with Flexible Transport Services, Transport Policy 14/6 (2007), 458-466, DOI 10.1016/j.tranpol.2007.09.001.

7 Charmaz K, Constructing Grounded Theory: A Practical Guide through Qualitative Analysis, Thousand Oaks, Wiltshire, 2006. Sage Publications.

8 Du S, Bhattacharya C B, Sen S, Reaping relational rewards from corporate social responsibility: The role of competitive positioning, International Journal of Research in Marketing 24/3 (2007), 224-241, DOI 10.1016/j.ijresmar.2007.01.001.

9 Eurostat, Modal split of passenger transport 2011, available at http://epp. eurostat.ec. europa.eu/tgm/refreshTableAction. do?tab=table $\{\&\}$ plugin $=1\{\&\}$ pcode=tsdtr $210\{\&\}$ language $=$ en last accessed: 20. September 2011.

10 Eurostat, HICP-annual average indices for transport prices; Passenger transport by road, Passenger transport by railway, 2011, available at http://epp.eurostat.ec. europa.eu/tgm/refreshTableAction. do? tab=table $\{\&\}$ plugin $=1\{\&\}$ pcode $=\operatorname{tsdtr} 310\{\&\}$ language $=$ last accessed: 20. September 2011.

11 Eurostat, GDP per capita in PPS, available at http://epp.eurostat. ec. europa.eu/tgm/table. do?tab=table $\{\&\}$ init=1\{\\&\}plugin= $1\{\backslash \&\}$ language $=$ en $\{\&\}$ pcode $=$ tsiebQ10 last accessed: 20. September 2011.

12 Gardner B, Abraham C, What drives car use? A grounded theory analysis of commuters' reasons for driving, Transportation Research Part F: Traffic Psychology and Behavior 10/3 (2007), 187-200, DOI 10.1016/j.trf.2006.09.004.

13 Glaser B G, Strauss A, The Discovery of Grounded Theory: Strategies for Qualitative Research, Hawthorn, New York, 1967.

14 Glaser B. G, Theoretical sensitivity: Advances in the methodology of Grounded Theory, Sociology Press, Mill Valley CA., 1978.

15 Hensher D A, Button K J (eds.), Handbook of transport modeling, Elsevier Science, Oxford, 2002. second ed.

16 Hodgsona F, Tighta M, Raising awareness of transport issues: The potential to bring about behavioral change?, International Journal of Sustainable Development \& World Ecology 6/4 (1999), 281-292, DOI 10.1080/13504509909470018.

17 Jenkins T, Gove B, Forte P, Frye J, Future of Transportation Interactive Qualifying Project Worchester Politechnic Institute, available at http://www.wpi.edu/Pubs/E-project/ Available/E-project-042810-131309/unrestricted/ Future $\left\{_{-}\right\}$of $\left\{_{-}\right\}$Tranportation $\left\{_{-}\right\}$IQP $\left\{_{-}\right\}$Final $\{\%\} 5 B 1\{\%\} 5 D . p d f$ accessed: 15. May 2011.

18 Jong G, Gunn H, Ben-Akiva M, A meta-model for Passenger and freight transport in Europe, Transport Policy 11/4 (2004), 329-344, DOI 10.1016/j.tranpol.2004.03.001.

19 Jong G C, Riet O, The Driving Factors of Passenger Transport, European Journal of Transport and Infrastructure Research 8/3 (2008), 227-250.
20 Kelemen-Erdős A, Stratégia és marketing a tömegközlekedésben (Strategy and marketing in public transport), Vezetéstudomány 37/12 (2006), 43-51.

21 Központi Statisztikai Hivatal, Budapest kerületeinek adatai, available at http://statinfo.ksh.hu/Statinfo/themeSelector $\cdot$ jsp?page= $2\{\&\}$ szst $=\mathrm{T}$ last accessed: 20 . September 2011.

22 Layder D, Grounded Theory: A Constructive Critique, Journal of the Theory of Social Behavior 12/1 (1982), 103-122, DOI 10.1111/j.14685914.1982.tb00441.x.

23 Leenheer J, Heerde H J, Bijmolt T H A, Smidts A, Do loyalty programs really enhance behavioral loyalty? An empirical analysis accounting for self-selecting members, International Journal of Research in Marketing 24/1 (2007), 31-47, DOI 10.1016/j.ijresmar.2006.10.005.

24 Mackett R L, Policies to attract drivers out of their cars for short trips, Transport Policy 8/4 (2001), 295-306, DOI 10.1016/S0967-070X(01)000257.

25 Malhotra N K, Marketingkutatás, KJK-KERSZÖV Jogi és Üzleti Kiadó Kft., Budapest.

26 Miles M B, Huberman A M, Qualitative Data Analysis: an expanded source book, Sage Publications, Thousand Oaks CA., 1994.

27 Moriarty P, Honnery D, Low-mobility: The future of transport, Futures 40/10 (2008), 865-872, DOI 10.1016/j.futures.2008.07.021.

28 Mulley C, Nelson J D, Interoperability and transport policy: the impediments to interoperability in the organisation of trans-European transport systems, Journal of Transport Geography 7/2 (1999), 93-104, DOI 10.1016/S0966-6923(98)00046-5.

29 Mulley C, Nelson J D, Flexible transport services: A new market opportunity for public transport, Research in Transportation Economics 25/1 (2009), 39-45, DOI 10.1016/j.retrec.2009.08.008.

30 Nijkamp P, Geenhuizen M, European transport: challenges and opportunities for future research and policies, Journal of Transport Geography 5/1 (1997), 4-11, DOI 10.1016/S0966-6923(96)00041-5.

31 Observatorio Ecónomico, Madrid Economy 2010, available at http:// WWw.madrid.es/UnidadesDescentralizadas/UDCObservEconomico/ MadridEconomia/Ficheros/MadridEconomia2010Ingles.pdf accessed: 22. June 2011.

32 Richardson A J, Ampt E S, Meyburg A H, Survey Methods for Transport Planning, Eucalyptus Press, Melbourne, 1995.

33 Sohail M, Maunder D. A. C, Miles D. W. J., Managing public transport in developing countries: Stakeholder perspectives in Dar es Salaam and Faisalabad, International Journal of Transport Management 2/3-4 (2005), 149-160, DOI 10.1016/j.ijtm.2005.06.001.

34 Sohail M, Maunder D. A. C, Cavill S, Effective regulation for sustainable public transport in developing countries, Transport Policy 13/3 (2006), 177 190, DOI 10.1016/j.tranpol.2005.11.004.

35 Strauss A, Qualitative analysis for social scientist, Cambridge University Press, Cambridge, 1987.

36 Strauss A, Corbin J, Basics of Qualitative Research, Thousand Oaks, Sage Publications Inc., California, 2008. third ed.

37 Vágási M, Integration of the sustainability concept into strategy and marketing, Periodica Polytechnica Ser. Soc. Man. Sci. 48/2 (2004), 245-260.

38 Whelan G, Johnson D, Modelling the impact of alternative fare structures on train overcrowding, International Journal of Transport Management 2/1 (2004), 51-58, DOI 10.1016/j.ijtm.2004.04.004.

39 Whetten D A, What Constitutes a Theoretical Contribution?, Academy of Management Review 14/4 (1989), 490-495, DOI 10.5465/AMR.1989.4308371. 